\title{
SOCIAL RESPONSIBILITY IN MARKETING OF THE FOOD INDUSTRY AND ITS DISTRIBUTORS ${ }^{1}$
}

\author{
Tanja M. Vujovič́2, Sonja M. Vujović3 ${ }^{3}$ Miloš Lj. Pavlovičc
}

\begin{abstract}
The paper analyzes the contemporary consumer's mentality (materialistic concept of consumption), which is greatly encouraged by numerous propaganda messages that are spread through various media. Human eating habits have been rapidly changing under the influence of media and other propaganda. People eat food of dubious quality, that is only in function of making larger profit without worrying about the health of people and other possible problems that can arise. In the focus of the research are food products advertisements that were broadcasted on the three most watched TV stations with national coverage in the Republic of Serbia. By analyzing the structure and slogans of most advertised food products, the authors came to the conclusion that the media are in direct function of food producers and distributers. Media and marketing, therefore, have great influence on consumption of unhealthy food, and it is in direct relationship with large profits of food producers and distributers. In such constellation of relations only the consumers are at loss.
\end{abstract}

Key words: marketing, social responsibility, food industry, food distributors, unhealthy food, profit.

JEL: L66, N50, M31, M37, Q13

\section{Introduction}

In order to increase profitability, the agricultural production increasingly begins to take the characteristics of industrial production. Over the time, it has become highly specialized,

1 This paper is the result of research within the project III 47023: "Kosovo and Metohija between national identi-ty and European integration", funded by the Ministry of Education, Science and Tehnlogical Development of the Republic of Serbia.

2 Tanja Vujović Ph.D., Associate Professor, University of Pristina, Faculty of Economics, Kolasinska street no. 156, 38220 Kosovska Mitrovica, Serbia, Phone: +381 659991404 , E-mail: tanja.vujovic@pr.ac.rs

3 Sonja Vujović Ph.D., Assistant Professor, University of Pristina, Faculty of Economics, Kolasinska street no. 156, 38220 Kosovska Mitrovica, Serbia, Phone: +381 66140 461, E-mail: sonja.vujovic@pr.ac.rs

4 Miloš Pavlović Ph.D., Professor, Belgrade Business School - Higher education institution for applied studies, Kraljice Marije street no. 73, 11000 Belgrade, Serbia, Phone: + 38164 27794 21, E-mail: milospavlovic84@,hotmail.com

EP 2017 (64) 3 (1277-1295) 
relies on monocultures, involves intensive processing of large areas by modern agricultural machinery and the intensive use of industrial inputs (fertilizers, pesticides, animal foofdstuff, veterinary drugs and compositions...). There are also created new highly productive species and breeds. All that is mentioned is in direct function of yield increasing. However, intensive agriculture, in the long term, causes various disturbances in the biological balance of agro-accelerates the destruction of the structure, and consequently the quality and fertility of the soil and leads to progressive destruction of biodiversity. Longer treatment with artificial fertilizers which are, except the basic plant nutrients (nitrogen, phosphorus and potassium) and micronutrients (Fe, Mn, $\mathrm{Zn}, \mathrm{Co}, \mathrm{B}, \mathrm{Mo}$ ), also consisted of heavy metals (lead, zinc, arsenic, and cadmium). It leads to accumulation of mentioned substances in the soil (soil degradation), penetration into ground water flows, high concentration in the air by evaporation etc. In Germany, the emission of nitrogen gas in the atmosphere is extremely high. $60 \%$ of that emission comes from agriculture. The German government is trying to solve this situation by introducing stricter regulations and encouraging changes in agricultural production methods. On the other hand, Denmark has set a target to convert agricultural output in 100\% organic and biodynamic, by the end of 2020 (Ilić, Krstić, Jovanović, 2017). In addition to the above mentioned negative effects, the incorrect and uncontrolled use of agrochemicals causes increased concentration of toxic and undesirable compounds in the plants, or any part of it which can be further used in human nutrition.This is bringing out the question of food health safety.

In addition, the food industry engaged in processing health and safety debatable agricultural products is, thanks to the technological processes of modernization and innovation, constantly expanding its product range and launching to market new food products thanks to the technological processes modernization and innovation. In this way, the industry has introduced a "new fashion" in human diet. As a result of these changes in the daily human diet there are products that contain increasing amounts of undesirable substances. Such substances are various additives, emulsifiers, preservatives, etc. A few decades ago, mentioned substances, could not even be imagined as an integral part of a human daily menu. Of course, such diet has resulted in the emergence of new diseases that are plaguing modern human.

The seriousness of this issue is supported by the fact that many poisons are legitimately involved in the food chain of the population. Rulebook on quality of animal feedstuff (last modified on February, 2014, by the Minister of Agriculture, Forestry and Water Management) specifies "maximum permitted levels "of ,undesirable components", i.e. toxins, such as arsenic, cadmium, fluorine, lead, mercury, nitrates, melamine and others that can be found in $1 \mathrm{~kg}$ of feedstuff. For example, The Rulebook is allowing the presence of arsenic (2-100 $\mathrm{mg}$ ), cadmium (1-30 mg), fluorine (0.5-3,000 mg), lead (5-400 mg), mercury (0.1-0.5 mg). There is no need for much intelligence to realize that these toxins that are allowed to be found in animal feedstuff, can also be found in milk and dairy products, meat, eggs and other food products that contain ingredients of animal origin. The risk for human health can be understood if we know that arsenic, for example, is disrupting tissue oxygenation, impairing blood and blood-forming organs, liver, kidneys and heart, acting paralytic on the smooth muscle of blood vessels, damages the lining of the airways and eyes, has a carcinogenic effect 
etc. Cadmium causes damage to the kidney, liver, bone, blood and blood-forming organs, causes irritation of mucous membranes of the airways and of the eye and causing lung cancer and prostate cancer. Mercury causes nausea, and vomiting, bloody diarrhea, heart failure, intestinal perforation, kidney damage, and damage to the nervous system, that is manifested through the loss of sensitivity in the fingers, tongue and around the mouth, impaired speech, swallowing and writing, visual field constriction and impairment, emotional instability, loss of concentration and memory, depression, hallucinations and even suicidal tendencies (Aranđelović, Jovanović, 2009)

Bearing all this in mind, there is a question about social responsibility primarily of the state and the legislator. They are, under the pressure of lobbyists and special interest groups, extending the value of allowed presence in food of some dangerous substances. There is also a question about social responsibility of farmers, food producers and distributors of food. All of them, although aware of negative treatment in primary food production, processing and distribution, sell and promote food to wide population of people. In this way, they stimulate the demand for such food affecting changes in eating habits, all to the detriment of consumers.

\section{Methodology}

This paper will present the authors understanding of current condition in society, considering food industry, food distributors and influence of marketing in a food production process and diet habits of the population, with a special focus on the Republic of Serbia. For the purpose of this paper, the authors analyzed TV advertisements of food products on the exact date for 24 hours on 3 most watched TV stations with national frequency (RTS1, PRVA TV, PINK). A specification of emitted advertisements for focused period will be shown in table, sorted by the producer, distributor, food product and slogan. That data, will be analyzed and sorted by the criterias such as most advertised or most interesting slogan, mostly broadcasted etc. According to that research, appropriate conclusions will be made.

\section{Some issues about the food as a concept and phenomenon}

According to the definition given by European Parliament and Council, „Food (or 'foodstuff') means any substance or product, whether processed, partially processed or unprocessed, intended to be, or reasonably expected to be ingested by humans. 'Food' includes drink, chewing gum and any substance, including water, intentionally incorporated into the food during its manufacture, preparation or treatment. It also includes drinking water "(Regulation (EC) No 178/2002). In a slightly altered form there is similar definition of ,food“" in a „Law of food safety of Republic of Serbia“" (Službeni glasnik, 41/2009). In addition to this definition of food in both of mentioned documents also can be found definitions of terms such as "food business", "food business operator", "risk", "risk analysis", "risk management", etc. In the literature that deals with food, there is more and more frequently in use the term "functional food", which is defined as the food that "apart from the usual nutritional effects, has a beneficial effect on one or more targeted functions of the body, in a manner that is relevant or to improve the state of health and of well-being and / or to reduce the risk of disease" (Scientific Concepts of Functional Foods in Europe Consensus Document, 1999). The most 
important purpose of the functional food, therefore, is not to satisfy the hunger, or to ensure essentialnutrients to human body, but to prevent disease, and to improve physical and mental condition of human (Jašić, 2010).

Food has several important functions in the body, such as structural, control-protective and energy. However, modern human is also experiencing food as a pleasure that engages all the senses, as the mystical world of smells, tastes and the possibility of taste seduction and as a "feast for the eyes". Nowadays, using food it become possible to express cultural identity and promote the dominant philosophy of a nation. Food alsobecomes an indicator of social status and symbol of religious, ethnic, generational and gender qualification, a reflection of lifestyle, part of important life events and emotional states, a matter of tradition, fashion, prestige, fashions etc.

Modern civilization and the neoliberal concept of economic development, food, as a means of survival and social and cultural phenomenon, has turned even in a lucrative business. As a result, food has received some other dimensions that had not been peculiar. Thus, food, among other things, has become an object of marketing, legislation, professional discussions about healthy diet, a key factor for geopolitical power, as well as the subject of international declarations, conventions and strategies.

Maybe more interesting role of food in modern period is as a factor of geopolitical power. Food production was one of freest human activities in period while it was produced on the basis of seed which has been passed from generation to generation. With the advent of the first hybrids that give higher yields than its natural counterpart, farmers, if wanted high-yield seeds, each year had to appear as a customer. Because of that, the production of seeds gradually passed from the hands of farmers, to the hands of corporations. In the beginning, corporations dealing with seeds were in state ownership, and after, thanks to the process of privatization and deregulation of this business activity, private sector has been involved in it. It has become very interesting for MNCs. A similar thing happened with the production of agrochemicals, fertilizers and agricultural machinery. In the last 40 years, drastic changes have been made in ownership of companies dealing with seed, food crops and other agricultural inputs for food production. There has been incredible augmentation of capital, in way that majorities of global companies, engaged in the production and sale of agricultural inputs, have become property of several major MNCs, as can be seen in Graphic 1.

Most current fusion in this sector is the acquisition of Monsanto (American company for the production of genetically modified foods) made by Bayer (German pharmaceutical giant). Acquisition occurred in September 2016, when Monsanto's shareholders accepted the offer of $\$ 128$ per share given by Bayer. It was $22 \%$ more than their current value on the New York Stock Exchange. Whole transaction was worth $\$ 66$ billion. This business combination has created the world's largest producer of seeds, pesticides and genetically modified crops with intentions to become the market leader in Europe, Asia and the US. It is practically got the role of a monopolist in world food production given that it will have a share in one-third of the world's markets. After these acquisitions, there are still a few major global "players" in the industry of seeds and crops, which also intend to merge (US 
conglomerate DuPont plans to invest $\$ 130$ billion in merging with DowChemicalCompany while ChinaNationalChemicalCorporation offered $\$ 43$ billion to buy Swiss agribusiness company Syngenta) (https://www.rt.com/business/359275-bayer-buys-monsanto/ Bayer confirms Monsanto takeover with $\$ 66 \mathrm{bn}$ bid). All this has the effect of narrowing the freedom of individual producers and the creation of their dependence on large MNCs.

This dependence is not kept at the level of individual producers, but also reflects on the entire food industry, and is globally transmitted to the relations between the countries. Countries that had the potential to invest their capital in research and development of new sorts of seed, more efficient agrochemicals, fertilizers and agricultural machinery have become superior to those countries that could not develop their own production. Those countries have become dependent on imports of these factors of production. Thus, industrial agriculture, which is based on non-renewable seeds and which, in addition, is chemically intensive, capitalintensive and intensive in terms of fossil fuel consumption, reduced food independence of countries importing these agricultural inputs. A country which alone can not provide enough food for its nation, consequently is loosing its positions and facing with the problem of dependency which itself generates a number of geopolitical issues and opens the door to effect the determination of the geopolitical objectives and priorities, in the final, leads to some kind of colonial slavery.

Graph 1. Three Firm Market Concentration: 2013
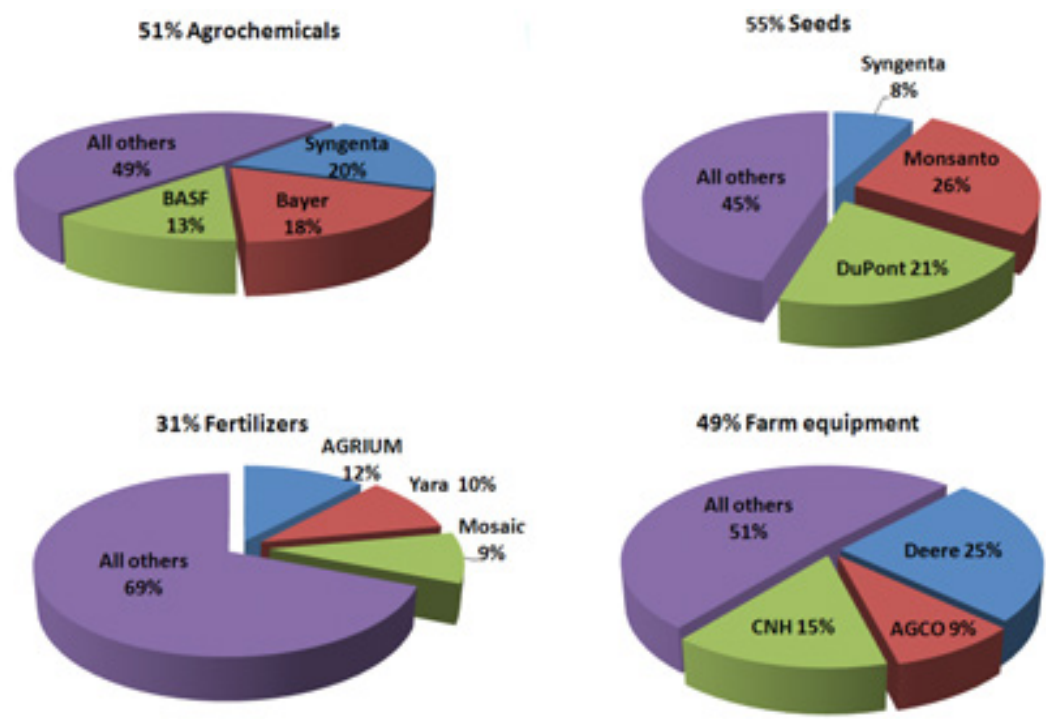

Source: http://www.etcgroup.org/sites/www.etcgroup.org/files/files/etcgroup_agmergers_22oct2015. pptx_.pdf

\section{Marketing and its social responsibility - some conceptual and theoretical issues}

Accelerated industrialization of the late XIX and early XX century led to the emergence of new products and technological processes, which had created problems for consumers. The 
essence of problems lies in fact that customers were not able to protect themselves from suspicious quality products that have flooded the market (for example: excessive amounts of sugar in soft drinks, the use of nitrates as preservatives in the food industry, etc.). Consumer Dissatisfaction of consumers was particularly pronounced in 30s of the last century, during the global economic crisis, because of the enormous price rising. That trend was stopped during the World War II, but in 60s again started to be actual. After a series of scandals, most notably those related to the drug named Thalidomide but also for the automotive industry, the consumer movement named Consumerism, began its development. It was some kind of social response to the immoral and irresponsible behavior of producers. Consumerism is a movement with numerous activities of individuals, organized groups, government agencies and institutions, as well as those companies in order to protect the rights of consumers. At the same time, a concept of corporate social responsibility began to develop. Its development was a result of a public debate on the operations of large corporations, the working conditions in them and their impact on the natural and social environment and key purpose of the business and its responsibilities arising from that purpose.

The term "social responsibility" for the first appeared in 1953 in the publication of Howard Bowen "Social responsibility of businessman". He tried to answer the question what level of responsibility to the society is reasonably to expect from a businessperson? Answering that question, Bowen took the view that the managers in their organization in the process of decision making, must take in consideration, except business goals, also the values of society and the environment in which they operate, and that they should "implement those policies bring those decisions and implement those actions in order to achieve social goals and benefits" (Bowd, 2003).

Peter Drucker, the guru of management, even though he stressed that the main goal of the company, and therefore management, is making a profit, he pointed that in addition, for the company it is very important to consider the impact of each business activity on society. Regarding this, Drucker also pointed that "the organization of the society of knowledge takes care of the society, within the limits of its competence, without compromising its business abilities" (Drucker, 1995).

According to the World Business Council for sustainable development, corporate social responsibility is a "firm commitment to promote sustainable economic development, and to improve the life quality, cooperates with employees, their families, local communities and society in at all" (Dahlsrud, 2008). This definition includes the economic aspect, since it talks about economic development, which should be sustainable, but also the social aspect, because it works to improve the quality of life of its stakeholders (employees with families, local community, society).

Within the European Union, for the first time CSR is being promoted as one of the new business policies in 2001 through the adoption of the Green Paper by the European Commission, in which the CSR is defined as, concept whereby companies integrate social and environmental concerns in their business operations and in relations with stakeholders, on a voluntary basis" (EC, 2001). The European Commission in October 2011 modified its definition of CSR, 
explaining CSR as, responsibility of companies for their impact on the environment" (EC, 2012) in order to highlight that CSR is not an additional element of business activities, but their essential component.

Along with the development of the CSR concept, developing the concept of social marketing that can be defined as "the use of marketing principles and techniques with the intention of targeting group accept them voluntarily, reject or modify certain behavior in favor of an individual, group or society as a whole, and all for the sake of health, injury prevention, environmental protection and the welfare of society" (Kotler, 2008). This discipline was created in 1971 when the term social marketing was first used by Philip Kotler and Gerald Zaltman in the article "Social Marketing: An Approach to Planned Social Change", in the Journal of Marketing, to describe "the use of marketing principles and techniques to propagate ideas, behavior and solution to some of the social problems" (Kotler, 2008).

\section{Food production - increasingly attractive business in Republic of Serbia}

Production, processing and preparation of food is a profitable business that brings huge profits. Despite the fact that the land, as a natural capital, is limited, and because of that, any increasing of agricultural production requires increased work capital, causing agricultural production applies the law of diminishing returns, companies in the field of agriculture, food industry and trade in agricultural products are increasingly prevalent in Serbia on the list of 100 most successful business organizations based on their operating performance and actual financial capacity. In 2015 in 100 most successful companies, even 22 are from food and agricultural sector. Therefore, they represent significant potential of the Serbian economy and possible carriers of economic growth in the next period (Table 1).

Table 1. Companies from agricultural and food sector listed in first 100 most successful companies in Republic of Serbia with largest net income in 2015. in 000 dinars

\begin{tabular}{|l|l|l|l|r|}
\hline \multicolumn{1}{|c|}{ Num. } & \multicolumn{1}{|c|}{ Rang } & \multicolumn{1}{|c|}{ Company name } & \multicolumn{1}{c|}{ Net Income } & $\begin{array}{c}\text { Number of } \\
\text { Employees }\end{array}$ \\
\hline 1. & 9. & Sunoko DOO Novi Sad & 4.324 .718 & 490 \\
\hline 2. & 16. & DELHAIZE Serbia DOO BG & 2.894 .396 & 7,801 \\
\hline 3. & 18. & INVEJ AD Beograd Zemun & 2.833 .064 & 49 \\
\hline 4. & 20. & Coca-Cola Hbc - Serbia DOO Zemun & 2.609 .088 & 829 \\
\hline 5. & 26. & IM Matijević DOO Novi Sad & 1.727 .580 & 1.647 \\
\hline 6. & 29. & C Market AD Beograd & 1.572 .115 & 3.280 \\
\hline 7. & 30. & FRICOM DOO Beograd & 1.461 .940 & 960 \\
\hline 8. & 31. & AGROMARKET DOO Kragujevac & 1.408 .706 & 330 \\
\hline 9. & 37. & Concern BAMBI AD Požarevac & 1.336 .941 & 902 \\
\hline 10. & 42. & SOJAPROTEIN AD Bečej & 1.125 .590 & 382 \\
\hline 11. & 43. & NELT CO. DOO Beograd & 1.119 .677 & 1.612 \\
\hline 12. & 45. & DM GRAIN CORN DOO BG & 1.082 .960 & - \\
\hline 13. & 46. & APA DOO APATIN & 1.014 .062 & 752 \\
\hline 14. & 60. & PTP DIS DOO Kraljevo & 734.140 & 1.264 \\
\hline 15. & 64. & ŠTARK DOO Beograd & 705.983 & 1.008 \\
\hline 16. & 77. & MPZ AGRAR DOO Novi Sad & 620.419 & - \\
\hline
\end{tabular}




\begin{tabular}{|l|l|l|l|r|}
\hline \multicolumn{1}{|c|}{ Num. } & \multicolumn{1}{|c|}{ Rang } & \multicolumn{1}{c|}{ Company name } & Net Income & $\begin{array}{c}\text { Number of } \\
\text { Employees }\end{array}$ \\
\hline 17. & 81. & VICTORIAOILAD Šid & 590.132 & 275 \\
\hline 18. & 82. & SOMBOLED DOO Sombor & 574.884 & 329 \\
\hline 19. & 83. & CARNEX DOO Vrbas & 573850 & 910 \\
\hline 20. & 94. & JAFADOO Crvenka & 512.018 & 373 \\
\hline 21. & 95. & Rubin AD Kruševac & 509.163 & 292 \\
\hline 22. & 98. & SWISSLION AD Beograd & 494.435 & 815 \\
\hline
\end{tabular}

Source: „A list of 100 best companies in Republic of Serbia in 2015. - data from official annual financial reports for 2015.“, Serbian Business Register Agency, Belgrade, 2016. - pp. 18-23.

This can be explained by the fact that the law of diminishing returns is neutralized by the process of agricultural production industrialization. In fact, the scientific and technological progress leads to abandonment of autarchic extensive agricultural production based on two field rotational cultivation practices and transition to a capital-intensive, monocultural agriculture production. This involves the use of agricultural machinery, irrigation systems, fertilizers, plant protection products and medicines for animal health and seeds (as in farming, and animal husbandry) generated by the process of selection and crossing different varieties and breeds. Because of this, even though agriculture recorded continuously increasing returns, it is more dependent on the agricultural machinery industry, energy, chemical industry and seed industry (agricultural inputs). There is also dependence from financial capital, which, increases production costs. Therefore, farming is increasingly starting to look like the industry, since it is characterized by specialization of labor, high level of costs and final products and production techniques that are similar to production line.

Thus, the value chain in agriculture is constantly expanding and includes companies engaged in the production of agricultural inputs, primary agricultural producers, processors, wholesalers and retail, exporters, banks and other financial organizations. Over the last few decades agricultural value chains, both in developed and in developing countries, have been buffeted by many changes due to the influence of numerous factors: globalization, liberalization, regulations change, government policies, technological development, progress in agricultural production, structural changes in trade, changes in market conditions, increasing export opportunities, urban population growth, the change of consumers' needs and expectations, socio-cultural effects, etc. (Zakić, Vukotić, Cvijanović, 2014).

Besides, Modern business conditions require from farmers strategic thinking and effective cooperative association, which should facilitate the joint participation of farmers in the more demanding markets, as well as better cooperation with government institutions (Simonović, Mihailović, Milovanović, 2016). All of this association and the connection is made to ensure the best possible position in the competitive environment, which stipulates that products are what consumers want, to reduce production costs and improve the quality of its products and services, or to be more efficient and effective than its competitors (Krstić, Radivojević, Stanišić, 2016). 
In addition, described method of agricultural production has bad influence on the soil - which is compacted and whose biological equilibrium is disturbed, leading to the appearance of resistant insect mutants and other pests and weeds which require a greater amount of the additional pesticide, all of which, ultimately, leads to the complete devastation of the land. Likewise, industrial animal production, which implies huge mechanized farms where animals are grown up, and even several thousands - of cattle, pigs, poultry under controlled conditions, results in the pollution of the soil, the air, surface and ground waters. All this leads to an increase in external costs - environmental costs. That cost is not included in produced units cost because they appear latter and become social or external costs.

Because of this, the interests of big capital invested in agricultural production (which began to dominate over the land and labor as primary factors of production) does not stop at the farm, but spread in the direction of financial institutions, agro-processing sector, segment of food trade and transport, up to the impact of government intervention and the intervention of supranational institutions. Thus, agricultural products, instead of being placed to the consumers in its elemental form, become inputs of processing and food sector, which have provided the "added value" in terms of adding work - because it is the only work in a position to produce surplus value, and profit. Therefore, agricultural products become "food products", "enriched" with "permitted amounts" of undesirable substances in the form of additives, emulsifiers, preservatives and other additives, which role is to improve the color, taste, durability and structure of the newly formed food.

\section{Diet habits, diseases and causes of death in Serbia}

Choosing the type of ingredients used in the diet, the incidence and frequency of meals during the day and preparation of food, in a word, eating habits, due to the fact that it is constantly repeated throughout life, certainly are the factors that most affect human health. Canadian doctor and Professor William Osler (lived in late XIX and early XX century) was saying that $90 \%$ of illness, except infections and accidents, are closely related to the lack of basic nutrients in the diet and that savings in healthy food today means payment of medical services in later stages of life. (available at: http://ezinearticles.com/?) Nutrition is willing and conscious act, but to a large extent depends on several different factors, such as culture and traditions, the influence of family and social environment, the food availability and accessibility, etc. It is very important also because of the fact that inadequate diet increases the risk of malnutrition and obesity, which is leading to various health disorders.

Research on health condition, eating habits, lifestyle and other factors that affect the health of residents in Republic of Serbia was conducted by the Ministry of Health of the Republic of Serbia. The results of the research were analyzed by the Institute of Public Health of Serbia "Dr Milan Jovanovic Batut" for three periods in 2000, 2006, and 2013. According to the results of these studies, every fifth resident of adults (19.7\%) do not think about health when choosing a food. About the connectivity of nutrition and health are thinking residents of Vojvodina (23.8\%), suburban settlements (22.8\%), men (26.3\%), lower educated (23.6\%) and the poorest residents $(25,7 \%)$. Yet it is encouraging that almost half the population of Serbia (49.1\%) due to health reasons have changed at least something in the diet in the year 
preceding the survey. Thus, one in five (21.1\%) reduced the intake of fat, $14.1 \%$ of the fat is changed, which are used as food, $15.7 \%$ reduced the intake of salt, 15.1\% sugar intake and 8.2\% reduced weight with diet (Ministarstvo zdravlja Republike Srbije i Institut za javno zdravlje Srbije „Milan Jovanović Batut”, 2014).

In Serbia in 2013 a habit to have breakfast every day had $78.1 \%$ of the population, at least one cup of milk and / or dairy products daily consumed $51.7 \%$ of the population in the diet is still mostly used white bread $(60.1 \%), 25.9 \%$ of the population used the animal fats for the preparation of meals, every eleventh resident said that put extra salt on food (9.1\%), at least twice a week, fish is on the menu had only $12.5 \%$ of the population every other citizen of Serbia is insufficient or never consumed fruits (54.4\%) and vegetables (fresh, frozen, conserved soup or freshmade juices) on a daily basis had consumed $57.1 \%$ of the population. On the basis of the measured values of a body mass index (BMI) was 40.4\% was fed normally the population, and more than half (56.3\%) were overweight, or predgojazno $(35.1 \%)$ and obese $(21.2 \%)$, and $3.2 \%$ of the population was undernourished.

More than half of the population of Serbia (51.8\%) smoked once in their lifetime, of which $81.7 \%$ of the population belonged to the category of daily smokers. What is particularly worrying being the fact that the $26 \%$ of population aged 15-24 are smokers. Another bad habit of our population is consuming alcohol and it is often a part of some customs, tradition or culture. In 2013, 53.9\% of the population has consumed alcohol at least once, but there are $4.7 \%$ of population that consume alcohols every day. The population of young people between 15 and 19 years, 53\% had consumed alcohol.

Concerning physical activity, as key determinants of energy balance and the control of body weight, and the factors which reduces the risk of contracting cardio and cerebra-vascular disease, diabetes, cancer, breast cancer and colon cancer, depression and the like., Research has shown that as much as $43,6 \%$ of the population during their work (which comprises paid and unpaid work, family care, studying or learning) is sitting or standing. Daily bike riding for at least 10 minutes is practiced by $10.4 \%$ of the population, a fitness, sports or recreation at least three times a week is practiced by $8.8 \%$ of the population, and intense physical activity aimed at strengthening the muscles, at least three times a week is practiced by only $4.8 \%$ of the population of Serbia.

According to the same Research, as a result of mentioned dietary habits and low physical activity chronic non-communicable diseases for decades are dominant in our country. Thus, the largest population (31\%) suffer from high blood pressure, the deformity of the spine, or other chronic problem with back (19.1\%), elevated blood lipids (12.9\%) and deformity of the door or other problem with chronic cervical spine $(12.3 \%)$, coronary heart disease or anginupektoris $(10.2 \%)$, degenerative joint disease-arthrosis $(9.3 \%)$, allergy $(8.8 \%)$, diabetes (7.6\%), depression (6.3\%) and kidney problems (5.6\%).

The most common causes of death in 2015, include: diseases of the circulatory system $52.7 \%$ (men $47.8 \%$ and women $57.6 \%$ ) tumors 20.6\% (23.5\% men and 17.5\% women) diseases of the respiratory system $5.3 \%$ (6.1\% of men and $4.5 \%$ of female), diseases of the digestive system $3.2 \%$ (3.5\% men and 2.9\% women), mental disorders and behavioral disorders $1.4 \%$ 
(1.3\% men, women 1, 6\%). (Institut za javno zdravlje Srbije „Milan Jovanović Batut”, 2016) These data indicate that poor eating habits significantly affect the poor health and mortality of the population in our country.

\section{Influence of TV commercials of food products on customer behavior - key factor of social responsible marketing}

Every year there is a large number of advertisements for various industrially produced food products. Advertised food products are often with high level of fats, sugar, salt and "enriched" with various additives, emulsifiers, preservatives, artificial colors and flavorings. For the purpose of advertising companies invest a lot of money (according to some researches, in 2012 the fast food industry in the world has invested \$ 4.6 billion for these purposes). While consumers believe that they are immune to media messages of food producers and distributors, and not "tricked", the fact is that such media activities have its result on market.

Research conducted at Yale University have confirmed the assumption that the advertising of food products increased food consumption by $45 \%$. After a series of experiments, it was found that children who were exposed to advertisements for various "snacks" ate 8.8 grams for 14 minutes more than they would normally eat. It is calculated that this rate chew, while viewing advertisements for food, for just 30 minutes per day lead to the introduction of additional $94 \mathrm{kcal}$, which leads to an increase of body weight of $10 \mathrm{lb}$. (4.54 kg) per year, if this input is not compensated by reduced intake of other foods or increasing physical activity. Similar results were obtained after studying the result of advertising to adults, except that they had the stronger influence of advertising on the selection of the food consumed. Thus, research has shown that TV commercials encouraging auto consumption of food regardless of hunger, and therefore significantly contribute to the obesity pandemic (Harris, Bargh, Brownell, 2009).

A number of food products advertisements on most watched Serbian TV channels (RTS1, Prva, Pink) on 03.02.2017. can be viewed on Table 2.

Table 2. Number of advertisements on 03.02.2017. in Serbia on 3 most watched TV channels in Serbia

\begin{tabular}{|c|c|c|c|c|c|c|}
\hline \multirow{2}{*}{ Num. } & \multirow{2}{*}{\begin{tabular}{|l|}
$\mathbf{P} \mathbf{r} \mathbf{o} \mathbf{d}$ u c e r / \\
distributer
\end{tabular}} & \multirow{2}{*}{ Product } & \multirow{2}{*}{ Slogan } & \multicolumn{3}{|c|}{ Number of repetitions } \\
\hline & & & & RTS1 & PRVA & PINK \\
\hline 1. & IDEA & $\begin{array}{l}\text { Potato, pork chop, Jacobs } \\
\text { instant coffee }\end{array}$ & Worth it! & 3 & 1 & 1 \\
\hline 2. & IDEA & $\begin{array}{l}\text { Eggs, cheese, sausage and } \\
\text { smoked sirloin }\end{array}$ & Worth it! & 1 & 1 & - \\
\hline 3. & IDEA & \begin{tabular}{|l|} 
Oranges, kebabs and sausages, \\
Balance yogurt, sugar
\end{tabular} & Worth it! & 1 & 3 & 5 \\
\hline 4. & IDEA & Cheese, ham, sour cream & Worth it! & - & - & 4 \\
\hline 5. & IDEA & Fresh fruit and vegetables & $\begin{array}{l}\text { Choose healthy, } \\
\text { pic fresh! }\end{array}$ & - & - & 1 \\
\hline 6. & DIS & $\begin{array}{l}\text { Oil „Cvet banata“, milka } \\
\text { chocolate }\end{array}$ & Pay less! & 1 & 1 & - \\
\hline 7. & DIS & $\begin{array}{l}\text { Raffaello balls, Radovanovic } \\
\text { white wine, red wine }\end{array}$ & Pay less! & 1 & 1 & 1 \\
\hline
\end{tabular}




\begin{tabular}{|c|c|c|c|c|c|c|}
\hline \multirow{2}{*}{ Num. } & \multirow{2}{*}{$\begin{array}{l}\text { P r o d u c e r / } \\
\text { distributer }\end{array}$} & \multirow{2}{*}{ Product } & \multirow{2}{*}{ Slogan } & \multicolumn{3}{|c|}{ Number of repetitions } \\
\hline & & & & \begin{tabular}{|l|} 
RTS1 \\
\end{tabular} & PRVA & PINK \\
\hline 8. & DIS & $\begin{array}{l}\begin{array}{l}\text { Fillet of beef, "Moja kravica"” } \\
\text { milk }\end{array} \\
\end{array}$ & Pay less! & - & 1 & 1 \\
\hline 9. & DIS & \begin{tabular}{|l|}
$\begin{array}{l}\text { Oranges in a net, 'Plazma' } \\
\text { cookie }\end{array}$ \\
\end{tabular} & Pay less! & - & 1 & - \\
\hline 10. & TEMPO & Yogurt, pork shoulder, flour & $\begin{array}{l}\text { TEMPO always in } \\
\text { action! }\end{array}$ & 3 & 8 & 4 \\
\hline 11. & TEMPO & $\begin{array}{l}\text { "DOBRA" oatmeal, flax seed, } \\
\text { whole grain bread "Basket" }\end{array}$ & $\begin{array}{l}\text { Time for healthy } \\
\text { decisions! }\end{array}$ & 1 & 2 & - \\
\hline 12. & TEMPO & $\begin{array}{|lll|}\begin{array}{l}\text { Coffee "C", Sombor feta } \\
\text { cheese }\end{array} & \\
\end{array}$ & $\begin{array}{l}\text { TEMPO always in } \\
\text { action! }\end{array}$ & - & - & 2 \\
\hline 13. & MAXI & Pork loin, apple - breburn & $\begin{array}{l}\text { Save with MAXI } \\
\text { bee, yours MAXI! }\end{array}$ & 2 & 9 & 3 \\
\hline 14. & MAXI & $\begin{array}{l}\text { Pressed ham, DONCAFÉ, } \\
\text { "Milka" chocolate and biscuits }\end{array}$ & $\begin{array}{l}\text { Save with MAXI } \\
\text { bee, yours MAXI! }\end{array}$ & - & 2 & - \\
\hline 15. & MAXI & \begin{tabular}{|l|} 
Milk "Dukat", chocolate \\
cream Nutella
\end{tabular} & $\begin{array}{l}\text { Save with MAXI } \\
\text { bee, yours MAXI! }\end{array}$ & - & 1 & 2 \\
\hline 16. & RODA & $\begin{array}{l}\text { Potatoes, smoked ham and } \\
\text { back, sirloin "Neoplanta", } \\
\text { "Dukat" yogurt, cheese "Ideal" }\end{array}$ & $\begin{array}{l}\text { Where MEGA } \\
\text { savings are! }\end{array}$ & 1 & - & 1 \\
\hline 17. & RODA & "Lav" beer & $\begin{array}{l}\begin{array}{l}\text { Where MEGA } \\
\text { savings are! }\end{array} \\
\end{array}$ & 1 & - & - \\
\hline 18. & RODA & Yuhor products Hello drinks & $\begin{array}{l}\text { Where MEGA } \\
\text { discounts are! }\end{array}$ & 1 & 2 & 1 \\
\hline 19. & RODA & Tuna, DON CAFÉ & $\begin{array}{l}\text { Where MEGA } \\
\text { savings are! }\end{array}$ & - & 1 & - \\
\hline 20. & Aroma markets & \begin{tabular}{|l|}
$\begin{array}{l}\text { Pork shoulder, tangerines, } \\
\text { pressed ham }\end{array}$ \\
\end{tabular} & & - & - & 10 \\
\hline 21. & AMAN & Lemon, smoked pork neck & $\begin{array}{l}\text { The king of low } \\
\text { pries! }\end{array}$ & - & - & 7 \\
\hline 22. & AMAN & $\begin{array}{l}\text { Pork neck and pork, eggs, } \\
\text { "Milka" chocolate }\end{array}$ & $\begin{array}{l}\text { The king of low } \\
\text { pries! }\end{array}$ & - & - & 2 \\
\hline 23. & Univer Export & $\begin{array}{l}\text { "Nektar" apple juice, pressed } \\
\text { ham, cucumber }\end{array}$ & & - & - & 6 \\
\hline 24. & SUPER VERO & $\begin{array}{l}\text { Chicken fillet, sausages } \\
\text { "Neoplanta". Water "Gala" } \\
\text { Grapefruit, "Pearl" cheese }\end{array}$ & $\begin{array}{l}\text { Much cheaper than } \\
\text { you can imagine }\end{array}$ & - & - & 1 \\
\hline 25. & Matijević & Pork loin, pork, chicken meat & \begin{tabular}{|l}
$100 \%$ from our \\
farm!
\end{tabular} & - & 4 & 7 \\
\hline \multicolumn{4}{|c|}{ TOTAL number of advertisements for food products on promotion } & 16 & 38 & 59 \\
\hline 26. & Diageo company & Johnnie Walker whiskey & $\begin{array}{l}\text { From the Scottish } \\
\mathrm{m} \text { o u } \mathrm{n} \text { t a i } \mathrm{n} \mathrm{s}, \\
\text { matured in barrels } \\
\text { of American oak. }\end{array}$ & 3 & - & - \\
\hline 27. & Coca Cola & Coca Cola drink & Taste the filing! & 4 & 10 & 7 \\
\hline 28. & Coca Cola & Schweppes drink & \begin{tabular}{|l|}
$\begin{array}{l}\text { Strong character } \\
\text { required! }\end{array}$ \\
\end{tabular} & - & 4 & 2 \\
\hline 29. & Coca Cola & „Fanta“ drink & Twisted joke! & & 3 & 2 \\
\hline
\end{tabular}




\begin{tabular}{|c|c|c|c|c|c|c|}
\hline \multirow{2}{*}{ Num. } & \multirow{2}{*}{$\begin{array}{l}\text { P r o d u c e r / } \\
\text { distributer }\end{array}$} & \multirow{2}{*}{ Product } & \multirow{2}{*}{ Slogan } & \multicolumn{3}{|c|}{ Number of repetitions } \\
\hline & & & & \begin{tabular}{|l|} 
RTS1 \\
\end{tabular} & PRVA & PINK \\
\hline 30. & AD IMLEK & "Moja kravica"yougurt & \begin{tabular}{|l|}
$\begin{array}{l}\text { Always } \\
\text { family! }\end{array}$ \\
\end{tabular} & 3 & 4 & - \\
\hline 31. & AD IMLEK & $\begin{array}{|lll|}\begin{array}{l}\text { Chocolate milk "Moja } \\
\text { kravica" }\end{array} & \\
\end{array}$ & Be a child! & - & 3 & 2 \\
\hline 32. & AD IMLEK & "Moja kravica" milk & Grow up happy! & - & 2 & 2 \\
\hline 33. & AD IMLEK & "Moja kravica" special yogurt & That's right! & & & 2 \\
\hline 34. & BAMBI & „,Wellnesscbreakfast"cookies & The day can start! & 2 & 4 & 3 \\
\hline 35. & BAMBI & „Plazma“ cookies & $\begin{array}{l}\text { All that you need } \\
\text { already exists, for } \\
50 \text { years! }\end{array}$ & & 3 & 3 \\
\hline 36. & ŠTARK & „Prima“ sticks & To chew tastes. & 1 & 3 & 2 \\
\hline 37. & Red Bull & Red Bull Energy Drink & It gives you wings! & 1 & 1 & - \\
\hline 38. & $\begin{array}{l}\text { A P A T I N S K A } \\
\text { PIVARA }\end{array}$ & Filtrated “Jelen" beer & Beer full of flavor! & 3 & 2 & \\
\hline 39. & Chipita & ,Seven days “croissant & \begin{tabular}{|l|}
$\begin{array}{l}\text { The future of } \\
\text { pastry! }\end{array}$ \\
\end{tabular} & - & 3 & 2 \\
\hline 40. & Ferrero & Ferrero Rocher & \begin{tabular}{|l|}
$\begin{array}{l}\text { Let your special } \\
\text { moments shine! }\end{array}$ \\
\end{tabular} & - & 4 & - \\
\hline 41. & Ferrero & TICK - TACK mints & \begin{tabular}{|l|}
$\begin{array}{l}\text { Freshness in two } \\
\text { words! }\end{array}$ \\
\end{tabular} & - & 3 & - \\
\hline 42. & Ferero & \begin{tabular}{|lrr} 
Kinder & Surprise, & Kinder \\
Bueno, & Kinder & penguin, \\
Kinder chocolate & \\
\end{tabular} & & 1 & 7 & - \\
\hline 43. & Ferero & Nutella euro cream & $\begin{array}{|lrr|}\text { A good } & \text { day } \\
\text { starts } & \text { with } & \text { good } \\
\text { morning! } & \\
\end{array}$ & - & 1 & - \\
\hline 44. & Wrigley & Airwaves gums & & - & 5 & - \\
\hline 45. & Wrigley & "Orbit" gums & Eat, drink, chew! & & 6 & - \\
\hline 46. & SOMBOLED & "President" butter & $\begin{array}{l}\text { Get the best slice } \\
\text { of life! }\end{array}$ & - & 4 & 2 \\
\hline 47. & SOMBOLED & „DUKAT“ fresh milk & \begin{tabular}{|l|}
$\begin{array}{l}\text { Dukat in harmony } \\
\text { with nature! }\end{array}$ \\
\end{tabular} & - & 1 & 4 \\
\hline 48. & MARS & Snickers chocolate & \begin{tabular}{|l|} 
When you're \\
hungry, you are not \\
your own!
\end{tabular} & - & 6 & - \\
\hline 49. & MARS & Twix chocolate & $\begin{array}{l}\text { Try both and pick } \\
\text { a side! }\end{array}$ & - & 6 & - \\
\hline 50. & Nestle & Nestle cheerios oats & $\begin{array}{l}\text { Tasty way to get } \\
\text { your cholesterol } \\
\text { low! }\end{array}$ & - & 4 & - \\
\hline 51. & McDonald's & McDonald's fast food & I love it! & - & 12 & - \\
\hline 52. & Marbo & "Clipsy" popcorn & \begin{tabular}{|l|}
$\begin{array}{l}\text { Always fresh and } \\
\text { ready! }\end{array}$ \\
\end{tabular} & - & 1 & 2 \\
\hline 53. & Marbo & Chipsy & \begin{tabular}{|l|} 
Every day tastes \\
better with a smile!
\end{tabular} & & 3 & 1 \\
\hline 54. & VLASINKA & "ROSA" water & What is important! & - & 3 & - \\
\hline
\end{tabular}




\begin{tabular}{|c|c|c|c|c|c|c|}
\hline \multirow{2}{*}{ Num. } & \multirow{2}{*}{$\begin{array}{l}\text { P r o d u c e r / } \\
\text { distributer }\end{array}$} & \multirow{2}{*}{ Product } & \multirow{2}{*}{ Slogan } & \multicolumn{3}{|c|}{ Number of repetitions } \\
\hline & & & & RTS1 & PRVA & PINK \\
\hline 55. & PIONIR DOO & "VITANOVA" cookies & $\begin{array}{l}\text { A healthy, natural } \\
\text { and tasty! }\end{array}$ & - & - & 39 \\
\hline 56. & PIONIR DOO & "Kidy" chocolate & \begin{tabular}{|l|} 
You should like \\
KIDY!
\end{tabular} & - & - & 2 \\
\hline 57. & PIONIR DOO & "Medeno srce" cakes & Share the love! & - & - & 3 \\
\hline 58. & Kraft foods & „Milka“" pralines & $\begin{array}{l}\text { Little things mean } \\
\text { love! }\end{array}$ & - & - & 7 \\
\hline 59. & Kraft foods & "Milka" chocolate & $\begin{array}{l}\text { Tenderness comes } \\
\text { from within! } \\
\text { One chocolate - } \\
\text { three experience! } \\
\end{array}$ & - & - & $\begin{array}{l}3 \\
3\end{array}$ \\
\hline 60. & Swisslion & "Banat" chocolates & & - & - & 3 \\
\hline 61. & Swisslion & Euro cream "Swisslion" & \begin{tabular}{|l|l|} 
We grow up \\
together!
\end{tabular} & - & - & 3 \\
\hline 62. & Kutil DOO & “Jaffa” juices & $\begin{array}{l}\text { Everyone win with } \\
\text { JAFFA juices! }\end{array}$ & - & - & 3 \\
\hline 63. & Vino Župa & "LaVita" juices & A joy of life! & - & - & 3 \\
\hline 64. & Nectar DOO & "Nectar" juices & It's not the same! & - & - & 1 \\
\hline 65. & Knežević trade & “Oki-boki” flips & $\begin{array}{|lr|}\begin{array}{l}\text { Always good } \\
\text { company }\end{array} & \\
\end{array}$ & - & - & 1 \\
\hline \multicolumn{4}{|c|}{ Total number of advertisments: } & 33 & 132 & 166 \\
\hline
\end{tabular}

Source: Table has made according to the advertisement program on 3 most watched TV stations in Republic of Serbia (RTS1, Prva, Pink)

As you can see from the table 2 on the day 03.02.2017. in the period from 00 to 24 on the RTS1 shows a total of 33 advertising of foodstuffs, the PRVA television 132 commercials and Pink 166 commercials. Out of this number on advertisements for various food products (fresh meat, meat products, cheese, milk, sweets, flour, sugar, coffee, beer and soft drinks) that are in large retail chains (IDEAS, MAXI -it DIS, RODI et al.), sold at special prices in the RTS 1 accounted for $48.5 \%$ of ad (16), at the first $28.8 \%$ (38 ad) and on Pink 35.5\% or a total of 59 advertisements. So, depending on which program the day followed, viewers had the opportunity to 16, 38 or 59 times to hear the message "worth it!", "You'll pay less", "Save with the MAXI-bee", "Where is the mega savings ", "king of low prices" or to view flushed auntie who busily pushing carts through the tempo hypermarket and hails to her also busy daughter: "tempo Zorica, turn up the tempo" to arrive on time to buy all of those products while there are still discount prices.

On that Friday, the most advertised were Pionirs "Vita nova" cookies with the slogan "A healthy, natural and tasty!" and "Here for 100 years, all that connects pioneer products is love" - as many as 39 times, to which are advertised and a pioneer of products such Kidy chocolate (Kidy should you like it!) - 2 times, and "Medeno srce" ("Share love") - 3 times. Vitanova biscuit is marketed as a" healthy natural and tasty ", although in itself, among other things, comprises an antioxidant sodium metabisulfite (E223), whose side effects may be bad for digestive tract, destroys the vitamin B1 and B12 and causes allergic reactions in 
asthmatics and designated as the substance used, and should be avoided. Furthermore, the biscuit contains a raising agent, ammonium hydrogen carbonate (E503), sodium hydrogen carbonate (E500), disodium diphosphate (E450), which can cause irritations, and the hard to digest (Janković, 2002).

Considering a number of broadcasts following advertisements were present: drinks CocaCola (CocaCola, Schweppes, Fanta) with the slogans: "Taste the filing!" Requires a lot of character! "' Creepy cool!", which are repeated for 17 times on PRVA TV, 11 on PINK TV and 14 times on RTS. After them there are advertisements of Ferrero (praline Ferrero Rocher, Kinder sweets, Tic-tac mints, Nutella chocolate cream), which are broadcasted for 15 times on PRVA TV, with the advertising slogan "Let your special moments shine!", which follows Ferrero Rocher praline and slogans "Leave it to the pleasure", "the most beautiful moments of our lives", "Discover the penguin in you", "Barbie figurines which are easy to combine "addressed to the youngest, because they follow the Kinder line of products created specifically for children. Products by Kraft Foods Company (Milka chocolate and a variety of Milka chocolate) advertised on TV Pink 13 times with the slogan "Small things mean love?" "Tenderness comes from inside "and "One chocolate three experience!". Right after them, according to the number of repeats, there are McDonald's products, which are with the slogan "I love it!" broadcasted 12 times on the PRVA TV, different MARS's chocolates, PRVA TV -12 times Wrigley's Orbit chewing gum and Airwaves - 11 times, Imlek dairy products ode - PRVA TV 9 and 6 times on PINK TV, etc., etc. Throughout the day aired only one advertisement of fresh fruits and vegetables that can be bought in IDEA with the slogan "Choose healthy, "Pick fresh" on Pink TV.

In addition to the advertisement of the food product on all three channels have been broadcast total 170 ads (for RTS1 - 3 ad, PRVA TV - 55 and PINK TV - 112) for various compositions calming bowel, reducing pain, strengthening bone, reduce blood sugar, increased potency, enhance immunity, reduce stress, relieve the airways. One gets the impression that the consumption of foods advertised inevitably leads to health problems.

According to what have been said, we can make a conclusion that most frequently advertised are unhealthy foods that are edible, but the ongoing production process lose their nutritional properties (sweets, soft drinks, fast food, snacks, etc.). If you pay attention to the slogans that accompanied the advertisements it can be seen that they are mainly focused on the emotions of the moment and the ongoing ("It must be like it", "Share the Love", "Little things mean love"). Their goal is to encourage and inspire, to create a spectacle and illusion, they are designed primarily for deeper, unconscious layers of the personality, creating a state of light trance or confusion, weakening consumers will and adherence to the spoken and unspoken commands in advertising material. In addition, a large number of advertisements placed emphasis on saving when purchasing products at fantastic prices and slogans that accompany them encourage immediate action.

In the opinion of many dealing with irritating commercials, it can be concluded that people are generally annoyed by the fact that advertisements for various kinder chocolates intended for children always show unrealistically nice tidy house and 
cheerful parents, which are almost impossible to find in everyday life. Advertisements for CocaCola resentment is what creates the impression that the consumption of Coca Cola sufficient condition to achieve a happy life full of love and endless entertainment, and advertisements for Milka chocolate showMilka cow sometimes as a cow and sometimes as a bull which at urban children creates confusion, and at those from rural areas provokes derision. Advertisements for SevenDays croassaint and "Clipsy" popcorn resentment to deceive consumers presenting them as fresh pastry or just made popcorn, which is, of course, far from the truth.

\section{Conclusion}

The modern world, which is driven by the logic of profit and whose development is based on the concept of neoliberal capitalism, took a primary properties from food, especially if it is perceived as a "functional food" - properties that affect the improvement of the state of health and well-being and / or to reduce risk of the diseases, a property that has food as a social interaction (the cause for the assembly), or a form of identity (national, gender, religious et al.), and turned it into a means for the accumulation of a profit, as well as in the means for the acquisition of geo-political power. As the huge amount of capital invested in both primary agricultural production and the food industry, it is necessary to provide a market for the thus obtained food products, to return the invested capital and ensure profits, and marketing given the task of food turned into a thing prestige and an indicator of social status and stock, a thing of fashion and fashions... With a large capital investment in the promotion of food products, marketing has managed to impose a new way of diet habits of modern human, which had as consequences more or less unhealthy foods in their daily menu.

By analyzing the advertising content that relates to food products which are broadcasted on the three most watched Serbian TVs, it can be concluded that consumers are "bombed" daily with a large number of commercial confectionery products (various sweets and snacks), carbonated soft drinks, fast food - that is, mainly products that are harmful to human health. All these signs are a real visual spectacle that accompanies the messages that they are directed to the emotions, and those customers into the world of imagination and fantasy. As the feeling after the material consumption of the product can never create that satisfaction how they created fantasy that the consumer has while watching the ad, this leads to frustration and dissatisfaction, which becomes a real driving force for further consumption to advertising content, and food products continued pursuit of pleasure. Thus, the modern human unwittingly drawn into a vicious circle and constantly moving between illusion and dissatisfaction, and becomes deeply unhappy, due to impaired physical and mental health, acquired excess weight, and the fact that it can not achieve the illusion of pleasure. Because all of mentioned, greater attention should be paid to increasing media education of consumers, but also insist on respect for ethics, morality and promotion of greater social responsibility of food producers, in order to create conditions for achieving sustainable development. 


\section{Literature}

1. Agencija za privredne registre (2016): Sto naj... privrednih društava u Republici Srbiji u 2015. godini - podaci iz redovnih godišnjih finansijskih izveštaja za 2015. godinu, Beograd, Srbija

2. Aranđelović, M., Jovanović, J. (2009): Medicina rada, Medicinski fakultet, Univerzitet u Nišu, Niš, Srbija

3. Bayer confirms Monsanto takeover with $\$ 66 \mathrm{bn}$ bid, (available at: https://www. rt.com/business/359275-bayer-buys-monsanto/)

4. Bowd. R. (2003): CSR - A Schools Approach to an inclusive Definition: Setting the Scene for Future Public Relations and Communications Research, Centre for Corporate and Public Affairs, Manchester Metropolitan University, UK; available at http://www.cipr.co.uk/groups/special/csrnetwork/special16e_3.htm

5. Commission of The European Communities (2001): Green paper: Promoting a European Framework for Corporate Sociate Responsibility, DOC/01/9, Brussels, Belgium

6. Dahlsrud, A. (2008): How Corporate Social Responsibility is Defined: An Analysis of 37 Definitions, Corporate Social Responsibility and Environmental Management, vol. 15, Issue January/February, pp. 1-13, John Wiley \& Sons Ltd and ERP Environment, New York, USA

7. Drucker, P. (1995): Postkapitalističko društvo, Grmeč, Privredni pregled Beograd, Srbija

8. Euro Commerce (2012): A renewed EU strategy 2011-14 for Corporate Social Responsibility, Brussels, Belgium

9. European Parliament, Council of Europe (2002): Regulation (EC) No 178/2002 of the European Parliament and of the Council, Official Journal of the European Communities, Brussels, Belgium.

10. Harris, J., Bargh, J., Brownell K. (2009): Priming Effects of Television Food Advertising on Eating Behavior, Health Psychology, vol. 28, No: 4, pp. 404413, American Psychological Association, Washington DC, USA

11. Ilić, I., Krstić, B., Jovanović, S. (2017): Environmental Performances of Agriculture in The European Union Countries, Economics of Agriculture vol. LXIV, no. 1, pp. 41-57, Institut za ekonomiku poljoprivrede, Beograd, Srbija

12. Institut za javno zdravlje Srbije „Dr Milan Jovanović Batut” (2016): Zdravstvenostatistički godišnjak Republike Srbije 2015., Beograd, Srbija,

13. Janković, S. (2002): Aditivi, Medicus, Vol. 3, No. 1, pp. 45-56. Medicinski fakultet, Univerzitet u Kragujevcu, Kragujevac, Srbija

14. Jašić, M. (2010): Uvod u biološki aktivne komponente hrane, Tehnološki fakultet, Univerzitet u Tuzli, Tuzla, Bosna i Hercegovina

15. Kotler, Ph., Roberto, N., Li, M. (2008): Socijalni marketing, Clio, Beograd, Srbija 
16. Krstić, B., Radivojević, V., Stanišić, T. (2016): Measuring And Analysis Of Competition Intensity In The Sugar Market In Serbia, Economics of Agriculture, Vol. 63, No. 2, pp. 389-407, Institut za ekonomiku poljoprivrede, Beograd, Srbija

17. Ministarstvo zdravlja Republike Srbije, Institut za javno zdravlje Srbije „Milan Jovanović Batut” (2014): Rezultati istraživanja zdravlja stanovnišva Srbije - 2013. godina, Beograd, Srbija

20. Simonović, Z., Mihailović, B., Milovanović, Z. (2016): Cooperatives And Farmers Association As A Model Of Entrepreneurship In Serbian Agriculture Regarding The Case Of Nisava District, Economics of Agriculture, vol. LXIII, no. 2, pg. (699-712), Institut za ekonomiku poljoprivrede, Beograd, Srbija

22. Zakić, N., Vukotić, S., Cvijanović, D. (2016): Organisational Models In Agriculture With Special Reference To Small Farmers, Economics of Agriculture vol. LXI, no. 1, pp. 225-236, Institut za ekonomiku poljoprivrede, Beograd, Srbija

23. Službeni glasnik Republike Srbije, br. 41/2009: Zakon o bezbednosti hrane 


\title{
DRUŠTVENA ODGOVORNOST U MARKETINGU PROIZVOĐAČA HRANE I NJENIH DISTRIBUTERA ${ }^{5}$
}

\author{
Tanja M. Vujovićc ${ }^{6}$ Sonja M. Vujović ${ }^{7}$ Miloš Lj. Pavlović ${ }^{8}$
}

\begin{abstract}
Apstrakt
U radu je analiziran savremeni potrošački mentalitet (materijalistički koncept potrošnje,) koji se u velikoj meri podstiče brojnim propagandnim porukama koje se šire putem raznih medija. Ljudske navike u ishrani se, pod uticajem medija i druge propagande, brzo menjaju. Ljudi jedu hranu sumnjivog kvaliteta, koja je samo u funkciji stvaranja većeg profita bez brige o zdravlju stanovništva i drugim problemima koji se mogu pojaviti. U fokusu su se našle reklame prehrambenih proizvoda koje su se emitovale na tri najgledanije televizije sa nacionalnom frekvencijom u Republici Srbiji. Analizom strukture najreklamiranijih proizvoda i slogana koji su ih pratili, autori su došli do zaključka da su mediji u funkciji proizvođača industrijski proizvedene hrane $i$ da oni u velikoj meri podstiču tražnju za nezdravim namirnicama zahvaljujući čemu ogromne profite ostvarujui mediji i proizvođači hrane i farmaceutska industrija. U ovakvoj konstelaciji međusobnih odnosa jedino je potrošač na gubitku.
\end{abstract}

Ključne reči: marketing, društvena odgovornost, hrana, proizvođači hrane, distributeri hrane, nezdrava hrana, profit.

5 Rad je rezultat naučno-istraživačkog rada u okviru projekta III 47023 "Kosovo i Metohija između nacionalnog identiteta i evrointegracija" koji finansira Ministarstvo prosvete, nauke i tehnološkog razvoja Republike Srbije.

6 Vanredni profesor, dr Tanja Vujović, Univerzitet u Prištini, Ekonomski fakultet, Kolašinska ulica br. 156, Kosovska Mitrovica, Srbija, Telefon: +381 6599914 04, E-mail: tanja.vujovic@pr.ac.rs

7 Docent, dr Sonja Vujović, Univerzitet u Prištini, Ekonomski fakultet, Kolašinska ulica br. 156, Kosovska Mitrovica, Srbija, Telefon: +381 6599914 04, E-mail: sonja.vujovic@pr.ac.rs

8 Redovni profesor, dr Miloš Pavlović, Beogradska poslovna škola - Visoka škola strukovnih studija, Ulica Kraljice Marije br. 73, 11000 Beograd, Srbija, Telefon: +381 6427794 21, E-mail: milospavlovic84@hotmail.com

EP 2017 (64) 3 (1277-1295) 